\title{
Honorary Board Of The Regional Competence (DKD) In The Installation Procedures For Nameplate Of Notary In Sukoharjo District
}

\begin{abstract}
Adi Candra Saputra ${ }^{1}$ and Maryanto ${ }^{2}$
Abstract. The purpose of this study was to: 1) To determine the competence of the Regional Ethics Council (DKD) under the Act in force nowadays. 2) To determine the barriers and solutions implementation competence Regional Honor Council (DKD) in the installation nameplate notary. The data used in this study are primary data, secondary data and data that can support tertiary, which is then analyzed by the method of normative.

Based on the results of data analysis stuffed in that: 1) the Honorary Council of Regions in Sukoharjo district authorities to build on the notary in the territory that is Sukoharjo against the code of professional conduct notary, as well as to investigate and adjudicate on members of notaries who have problems related to violations of the code of professional conduct notary in the decision can in the form of a. Coaching, oral or written warning, $b$. Stopping notary within a certain period, c. Dishonorable discharge. 2) Barriers occurring in the implementation of competence honorary board area Particularly in the area Sukoharjo need for affirmation should have from the beginning of a notary at the time of the oath-taking should be informed related to the code of conduct in this regard the implementation of the nameplate notary, only drawback at the time of the decision oath, honor council areas were excluded.

Keywords: Competence of the Regional Ethics Board; Board Name Notaries; Notary
\end{abstract}

\section{Introduction}

Indonesia is a unitary state, where there is a rule in the rule of law. Ensure certainty, order and protection of the law, with a core of truth and justice in the traffic law generally requires evidence clearly define the rights and obligations of a person as a subject of law in society. ${ }^{3}$ In Act No. 2 of 2014 concerning amendments to the Act No. 30 of 2004 on Notary, grounding sociological presence of a Notary due to the needs of society against Notaries Related Notary Services in various business relationship banking, land, development, social in all fields that occurred in Indonesia.

Article 1 paragraph 1 stated that the notary is a public official who is authorized to make an authentic deed and have more authority as referred to in this Act or under the Act other. Position carried Notary is a position of trust given by the law and society, in the running position of a Notary is not enough to just have the legal skills but also must be based on responsibility in carrying out the trust given to him by upholding moral values, ethics laws and the dignity and nobility of his position, because if it is passed by a Notary public, will be harmful to the public it serves. The role and authority of the Notary is very important, therefore, Notary must be able to perform his profession in a professional manner.

\footnotetext{
1 Students Master of Notary, Sultan Agung Islamic University Semarang email saputra.adicandra@gmail.com

2 Faculty of Law Universitas Islam Sultan Agung

3 Sjaifurrachman, 2011, Aspek Pertanggung Jawaban Notaris dalam Pembuatan Akta, Mandar Maju, Bandung, p.1.
} 
The function and role of the notary in the national development movement of nowadays increasingly complex and increasingly widespread, so that the smooth and legal certainty of all the parties is determined by the services and products produced by the notary law. The government is offering some of its powers to the notary and notary public as service users hope that the services provided by notaries have value and weight are reliable. ${ }^{4}$

Notary as the public official entrusted must hold not only on legislation alone, but also on the code of ethics profession, because of the absence of a code of ethics, the dignity and status is the authority that needs to be observed, searched and found by a notary, because authority this may be already present in the legislation, and also the new authority will be born after the birth of the legislation new. ${ }^{5}$

Notary good behavior can be obtained based on the code of conduct. The position of a code of conduct for Notary is very important, this is because:

First, and not just because of the Notary is a profession that needs to be governed by a code of ethics, but also because of the nature and the nature of work of notaries who strongly oriented towards legalization, so that it can be fundamental to the main law on the status of property, rights and obligations of the clients who use the services of a Notary. Second, to prevent injustice as a result of granting the status of property, rights and obligations that are not in accordance with the rules and principles of law and justice, so as to disrupt public order and also interferes with individual rights of people seeking justice, then the world notary is necessary a code of ethics and modern.

In addition to the Notary obligations under Article 16 paragraph (1) UUJN, a notary must always behave and act in accordance with the code of professional conduct Notary. Notary obligations under Article 3 of the Notary Code (KEN) Indonesian Notary Association (INI). Enforcement of the code of ethics is essentially carried out by the Honorary Board of the Notary. Board of trustees pursuant to Article 1 point (8) code of conduct notary has the understanding and duties as follows: "The Council of Honor is the equipment of the Association as an agency or institution which is independent and free from bias in the Association which is responsible for:

- Do the coaching, guidance, supervision, reform member of upholding the code of ethics;

- Examine and take a decision on the alleged violation of the code of conduct that is internal or that are not related directly to the public interest;

- Providing advice and opinions to the Supervisory Council for alleged violations of the Code and Notary office. "

Enforcement of the code of conduct notary at the district / city carried out by the Regional Ethics Board. It is stated in Article 7 letter c notaries code of ethics, which reads: Supervision over the implementation of the Code was carried out in the following manner:

- On the first level by the Indonesian Notary Association of Regional and Local Honorary Council;

- On appeal by the Regional Board Indonesian Notary Association Honor Council Regional clan;

- At the end of the level by the Central Board Indonesian Notary Association and the Honorary Board of the Center.

\footnotetext{
${ }^{4}$ Suhrawardi K. Lubis, 2010, Etika Profesi Hukum, Sinar Grafika, Jakarta, p 35.

${ }^{5}$ Brierly Napitupulu, "Hubungan Peraturan Jabatan Notaris Dan Kode Etik Dalam Pelaksanaan

Tugas Notaris", http://www.magister-kenotariatan.blogspot.com, accessed March 9, 2013.
} 
Code of professional conduct is the result of self-regulating professions in question and realize the intrinsic moral value and not imposed from the outside, the code of ethics only become effective by the ideals and values of living within the profession itself. ${ }^{6} \mathrm{~A}$ profession in carrying out its functions should be conducted honestly, the principles were formulated in a disciplinary rules and sanctions for violations. Notary Code constitutes the entire moral principle guidance in running the Notary office.

The scope of the code of conduct notarized under Article 2 Notary Code applies to all member associations and others who assume and execute the Notary office, both in the implementation of the office as well as in everyday life. Notaries may be penalized if proven to have committed a violation of the provisions contained in KEN. The existence of a code of conduct aims to be a Notary Public Notary profession can be run by professionals with motivation and orientation on intellectual skills as well as arguing rationally and critically and uphold the moral values.

Honorary council area has a very important competence in the enforcement of the code of conduct notary. Honorary council area is a strategic position because it relates directly to the notary in the district or city level. In such cases the local board of trustees of parties who know all kinds of code violations committed by a notary.

In Sukoharjo district, there are indications of violations of the code of conduct notary. The breach caused by the element of self-promotion through the installation of nameplate notary who exceed the limits prescribed code of conduct notary. Nameplate've written notary / PPAT the real mounted above the entrance to the notary's office. In addition there is a typing error in the contents of nameplate notary, which only includes the name and address themselves. Then nameplate that reads Notary Office. Later in the nameplate anyone writing its contents be made one with PPAT. As well as the nameplate Notary made more than one. This is of course contrary to Article 3, paragraph (9) of the Code requires notaries who notarized:

"Add 1 (one) signs in front / in the office environment with a choice of size of $100 \mathrm{~cm} \mathrm{x}$ $40 \mathrm{~cm}, 150 \mathrm{~cm} \times 60 \mathrm{~cm}$ or $200 \mathrm{~cm} \times 80 \mathrm{~cm}$, containing:

- Full name and a valid title;

- Date and number of the Decree of the appointment of the latter as a Notary Public.

- The locus;

Office address and phone / fax number. Basic white sign with black letters and writings on the nameplate should be clear and easy to read. Except in an office environment is not possible for the installation of the sign in question ".

Based on the background mentioned above, the authors wanted to further investigate the issues are: 1) how the competencies of the Honorary Board of Regions under the Act in force nowadays. 2) how the barriers and solutions implementation of the Regional Ethics Board competence in the installation of nameplate notary.

\section{Research methods}

Metode approach used in this research is a normative juridical approach. Specifications descriptive analytical research. Types and sources of data using secondary data and primary data as well as the use of primary legal materials, secondary law and tertiary legal materials. The collection of data through library research and field study. Qualitative data analysis and deductive.

\section{Results and Discussion}

\footnotetext{
${ }^{6}$ Supriadi, Etika dan Tanggungjawab Profesi Hukum di Indonesia, Sinar Grafika, Jakarta, 2006,
} p.23. 


\subsection{Honorary Board of the Regional Competence (DKD) under the Act in force nowadays}

Notaries code of conduct is the norm established and accepted by the IT profession association, the only legitimate organization and notary bond set by UUJN No. 2 In 2014, directing or instructing members how it should be and guaranteeing the quality of moral (integrity notary) in the eyes of society. If one member of the notary profession associations (INI) do deviate from the code of ethics, then INI must finish by its own power (via the Council of Honor INI). ${ }^{7}$

Rule notary code of conduct is now outdated and far from the development of modernity. The next generation seemed not able to improve and update the rules in accordance with the modernization of the notary. Board is now more practical and selfish thinking, so prefer a personal interest (opportunists), irrespective of his devotion to IT organizations. They are rigid (rigid, normative, dogmatic) and less egalitarian, dynamic (progressive) in understanding the application of the code of conduct notary. Abandonment of the code of conduct plus a selfish organization committee led to more freely handful of actors who tarnished the profession.

Honorary Council of Notaries (MKN) is a body that has the "authority to conduct coaching Notary" and the obligation to give consent or refusal for the purpose of investigation and legal proceedings, on making photocopies of minutes of the deed and the calling of a Notary to attend the examination relating to the deed or protocol notary Notaries who are in storage. ${ }^{8}$

Associated with the supervision of a notary before changes UUJN particularly regarding the Notaries inspection license granted by the Regional Supervisory Council (MPD). However, the authority is revoked by the decision of the Constitutional Court Number 49 / PUU-X / 2012.

Then, after the enactment of Act No. 2 of 2014 on the Amendment of Act No. 30 of 2004 concerning Notary (UUJN), introduced Notary Institute Honorary Council (MKN). It can be seen in Article 66 paragraph (1) UUJN that is in the interests of judicial proceedings, investigators, prosecutors or judges with the approval of the competent Notary honor assemblies:

- take photocopies Minuta Deed and / or letters attached to Minuta Deed or the Protocol Notary Notaries in storage, and

- Notary call to be present in the examination relating to the Deed or protocols that are in storage Notary Public Notary.

Furthermore, as the implementation of Article 66A paragraph (3) UUJN, issued the Regulation of the Minister of Justice and Human Rights of the Republic of Indonesia Number 7 of 2016 concerning Notary Honorary Council.

Under the Articles of Association of Indonesian Notary Association Article 12, the Honorary Board of the fittings gathering of some of the members elected from ordinary members and the nursing Notary, dedicated and loyal to the clubs, good personality, wise and prudent, so that it can become a role model for members and appointed by congress for a term equal to the term of office of stewardship.

Based on Article 12 point (2) Articles of Association of Indonesian Notary Association Honor Council is authorized to:

\footnotetext{
${ }^{7}$ Ibid, p. 180

${ }^{8}$ Article 1 (1) Permenkumham No. 7/2016 of the Honorary Council of Notaries.
} 
- Providing guidance, supervision, coaching members in the enforcement of the code of ethics and uphold the Notary.

- Examine and take a decision on the alleged violation of the code of ethics Notary.

- Giving advice and opinions to the Supervisory Council and / or the Honorary Council of Notaries of alleged code violations Notary and Notary office.

- Coordination, communication, and relates directly to members and parties - parties that are directly related to the implementation and enforcement of the code of conduct Notary.

- Make regulations for the enforcement of the code of conduct in the Notary together - at the central committee.

Regional Honors Council in Sukoharjo district authorities to build on its territory, namely the notary in Sukoharjo against notary professional code of ethics, as well as to investigate and adjudicate on members of notary problematic with regard to violations of professional ethics can be a notary public in the decision 1. Development, verbal or written warning 2. Stopping notary within a certain timeframe, 3. Dismissal disrespect. ${ }^{9}$ In this case the procedures for the installation of nameplate notary in Sukoharjo district where the notary did a lot of violations related to nameplate notary about nearly $80 \%$ of violations. The amount is not small, when the board of trustees area Sukoharjo conduct an examination of the notary who committed the offense when in examination notary saying that the associated mounting the nameplate still follow nameplate seniors which seniors signboards there are right and some are wrong.

Nameplate in accordance with Article 3, paragraph (9) of the Code requires notaries who notarized:

"Add 1 (one) signs in front / in the office environment with a choice of size of $100 \mathrm{~cm} \mathrm{x}$ $40 \mathrm{~cm}, 150 \mathrm{~cm} \times 60 \mathrm{~cm}$ or $200 \mathrm{~cm} \times 80 \mathrm{~cm}$, containing:

- Full name and a valid title;

- Date and number of the Decree of the appointment of the latter as a Notary Public.

- The locus;

Office address and phone / fax number. Basic white sign with black letters and writings on the nameplate should be plain and easy to read. Except in an office environment is not possible for the installation of the sign in question ".

Sukoharjo district honors council stated that the sign must be independent. Violations committed by a notary in Sukoharjo in this case the board of trustees of Sukoharjo to provide guidance to the notary wrong in the implementation of the nameplate, to give explanations about the implementation of the nameplate are correct and related sanctions given by the board of trustees of the area only given verbal warning and be given an explanation regarding the nameplate.

\subsection{Barriers and Solutions competency implementation of the Regional Ethics Council (DKD) Installs Nameplate of Notary}

Barriers that occur in the implementation of the competence of the board of honor area Particularly in the area Sukoharjo need for affirmation, it should have from the beginning of a notary at the time of the oath-taking should be informed related to the code of conduct in this regard the implementation of the nameplate notary, only drawback at the time of the oath-taking, board of trustees and the supervisory council is not involved. ${ }^{10}$ The solution of the Honorary Board of the District Sukoharjo, namely:

\footnotetext{
${ }^{9}$ Interview with Sarwondo as informant, dated August 14, 2019, Notary Office Sarwondo

10 Ibid.
} 
According to writer and informant, implementation competence honorary board area from the beginning when an oath, minimal assembly supervisor regions and councils kehormtan involved, because so far there has been no involvement of relevant assemblies regional supervisory and board of trustees to provide input and information related to the implementation of the code of conduct especially in hairdressing how the implementation of the nameplate notary. So that the new notary in terms of installation nameplate correctly, so that no more violations of the code of conduct. ${ }^{11}$

\section{Closing}

\subsection{Conclusion}

Based on the research results can be concluded as follows:

- Regional Honors Council in Sukoharjo district authorities to build on its territory, namely the notary in Sukoharjo against notary professional code of ethics, as well as to investigate and adjudicate on members of notary problematic with regard to violations of professional ethics can be a notary public in the decision 1 . Development, verbal or written warning 2. Stopping notary within a certain timeframe, 3. Dismissal disrespect.

- Barriers that occur in the implementation of the competence of the board of honor area Particularly in the area Sukoharjo need for affirmation, it should have from the beginning of a notary at the time of the oath-taking should be informed related to the code of conduct in this regard the implementation of the nameplate notary, only drawback at the time of the oath-taking, honorary council areas were excluded.

\subsection{Suggestion}

- Should their firmness in this case the Regional Ethics Council into imposing sanctions against the notary who commits an offense related to the implementation of the installation of nameplate Notary.

- Regional Ethics Board must be included in the oath the notary, so that the board of trustees can both provide guidance related to nameplate notary so that no fault or breach the code of conduct related to the installation of nameplate Notary.

\section{Bibliography}

[1] Sjaifurrachman, 2011, Aspek Pertanggung Jawaban Notaris dalam Pembuatan Akta, Mandar Maju, Bandung.

[2] Suhrawardi K. Lubis, 2010, Etika Profesi Hukum, Sinar Grafika, Jakarta.

[3] Brierly Napitupulu, "Hubungan Peraturan Jabatan Notaris Dan Kode Etik Dalam Pelaksanaan Tugas Notaris", http://www.magister-kenotariatan.blogspot.com, diakses tanggal 9 Maret 2013.

[4] Supriadi, 2006, Etika dan Tanggungjawab Profesi Hukum di Indonesia, Sinar Grafika, Jakarta.

[5] Permenkumham No. 7/2016 tentang Majelis Kehormatan Notaris.

[6] Hasil wawancara terhadap narasumber Sarwondo, tanggal 14 Agustus 2019, Kantor Notaris Sarwondo

[7] Interview with Sarwondo as informant, dated August 14, 2019, Notary Office Sarwondo

${ }^{11}$ Ibid. 